1978. Proceedings of the Annual Meeting of the Berkeley Linguistics Society 38.

DOI: http://dx.doi.org/10.3765bls.v4i0.2198

Published for BLS by the Linguistic Society of America

Impersonal Passives and the Unaccusative Hypothesis ${ }^{*}$

David M. Perlmutter

UCSD

1. The Phenomenon

A number of languages have impersonal passives, a phenomenon illustrated by the following sentences of Dutch:

(1) Er wordt door de kinderen op het ijs geschaatst.

'It is skated by the children on the ice.'

(2) a. Door de kinderen wordt (er) op het ijs geschaatst.

'By the children it is skated on the ice.'

b. Op het ijs wordt (er) door de kinderen geschaatst.

'On the ice it is skated by the children'

These sentences have passive morphology - that is, the verb is in the past participial form, accompanied by the auxiliary verb worden, and the initial 1 is marked with the preposition door, which marks Passive chomeurs in Dutch. (1) also features the dummy er, where it shields the verb from clause-initial position. Different varieties of Dutch differ with respect to whether or not er appears in sentences such as those in (2), where some other element of the clause shields the verb from initial position. The distribution of er in such sentences has been studied for two varieties of Dutch by Maling and Zaenen (to appear).

Although the universal characterization of impersonal passives in $\$ 3$ is claimed to be valid for all kinds of impersonal passives, this paper will be concerned exclusively with impersonal passives of intransitive clauses, ignoring the impersonal passives of transitive clauses that exist in many languages.

2. The Theoretical Issues

Some linguists have recently based some rather far-reaching claims about syntax on impersonal passives. For example, Keenan (1975), Comrie (1977), and Jain (1977), reacting to the universal characterization of Passive as advancement of 2 to 1 given in Perlmutter and Postal (1974) and made explicit in Perlmutter and Postal (1977), claim that impersonal passives show that Passive cannot be characterized as an advancement, but must be treated as a demotion of a l, with advancement of a 2 to 1 as a languageparticular option. Since they propose that Passive is an example of "spontaneous chomage," they also deny the validity of the Motivated Chomage Law [Perlmutter and Postal (1977, to appear a) ].

At issue are the answers to the following questions:

(3) a. Are passives and impersonal passives the same phenomenon?

b. Is Passive the advancement of a 2 to 1 ?

c. Is the Motivated Chomage Law valid?

Copyright (c) 1978 by David M. Perlmutter 
(3a) is formulated rather vaguely, but it implicitly plays a role in the controversy that has arisen over impersonal passives. If one were to deny that impersonal passives are passives, 1 then they would have no bearing on (3b).

The answers to the questions in (3) that are given by Keenan, Comrie, and Jain contrast with those to be defended in this paper, in accordance with the proposal for impersonal passives in Perlmutter and Postal (to appear $b$ ):

(4)

$\begin{array}{lll} & \frac{K, C}{2} \& J & \frac{P \& P}{Y e s} \\ \text { a. } & \text { Nes } & \text { Yes } \\ \text { c. No } & \text { No } & \text { Yes }\end{array}$

$(4 b-c)$ thus sum up the basic points at issue. The major goal of this paper is to provide an argument in favor of the affirmative answers to $(4 b-c)$.

Impersonal passives also raise another issue of concern to general linguistic theory - that of the validity of the Final I Law [Perlmutter and Postal (to appear a)]. Many languages have impersonal passives which lack a surface 1. This is the case in Dutch in those dialects in which er does not appear in (2), in German in examples such as

(5) Hier wurde den ganzen Abend getanzt. 'It was danced here all evening.'

and in many languages, such as Turkish, in which a dummy never appears in the surface realizations of impersonal passives:

(6) Burada çalışıır.

'Here it is worked.'

A second purpose of this paper is to provide evidence that all such examples have a final 1, in conformity with the Final I Law, although they lack a surface 1 .

3. A Universal Characterization of Impersonal Passives

According to the proposal in Perlmutter and Postal (to appear b), which is defended here, impersonal passives universally involve a dummy which advances from 2 to 1 . Under this analysis of impersonal passives, the relational network associated with (1) can be represented as the following simplified stratal diagram: ${ }^{2}$

(7)

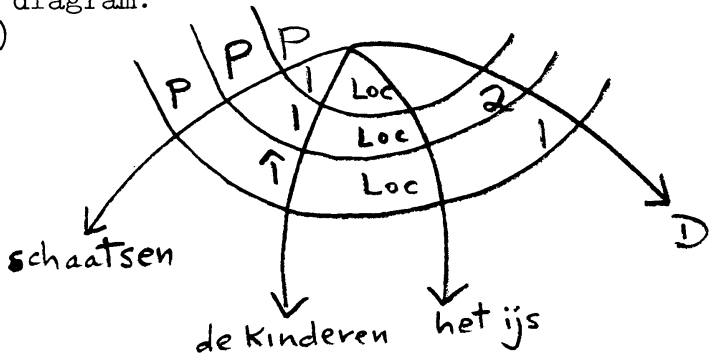


' $D$ ' represents a dummy, which in some Dutch impersonal passives is realized as er. (7) represents the fact that the dummy bears the 2-relation in the second stratum and the l-relation in the third stratum, putting the initial $I$ en chomage. Compare ( $I$ ) and (7) with the so-called 'personal' passive

(8) a. De kaas werd door de kinderen gegeten. 'The cheese was eaten by the children.' b.

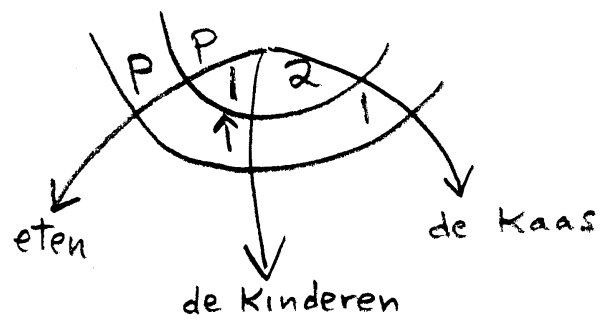

Both ( 7 ) and (8b) involve an advancement from 2 to 1 , where the stratum in which the advancee heads a 2-arc also includes a l-arc. Thus, both ( 7 ) and ( $8 \mathrm{~b})$ fall under the universal characterization of Passive proposed in Perlmutter and Postal (1977). Internal to Dutch, these factors determine the passive morphology of worden + past participle for the verb and marking with door for the chomeur. Since it involves an advancement from 2 to $I$, I will refer to the analysis of impersonal passives in (7) as the advancement analysis of impersonal passives. ${ }^{3}$

The advancement analysis can be contrasted with the demotion analysis of impersonal passives, which can be reconstructed as involving a relational network for ( 1 ) of the following form (given as a stratal diagram):

(9)

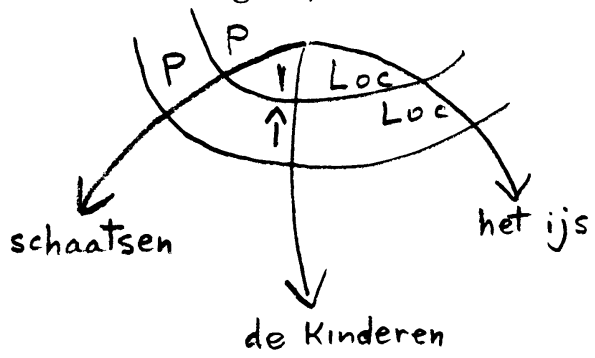


(9) simply involves 'demotion' of the initial 1 to chomeur. There is no dummy and no advancement.

In this paper I give one argument in favor of the advancement analysis of impersonal passives over the demotion analysis. The argument is based on the interaction of this phenomenon with an independently motivated hypothesis about linguistic structure the Unaccusative Hypothesis. The basic claims of the Unaccusative Hypothesis are sketched briefly in $\$ 4$.

4. The Unaccusative Hypothesis

The basic claim of the Unaccusative Hypothesis is simply stated:

(10) Certain intransitive clauses have an initial 2 but no initial 1 .

For example, under the Unaccusative Hypothesis it is claimed that the English sentence

(11) Gorillas exist.

is associated with the relational network given in (12a) and as a stratal diagram in ( $12 \mathrm{~b})$ :

(12)
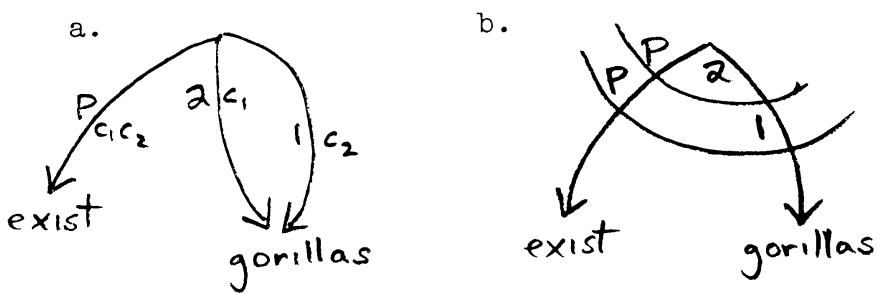

Gorillas is initial 2 but final 1. The advancement in (12) is called Unaccusative. It differs from Passive in that in cases of Unaccusative, the stratum in which the advancee heads a 2 -arc does not also contain a 1-arc.

The terminology defined below will facilitate discussion: ${ }^{4}$

(13) a. A transitive stratum contains a 1-arc and a 2-arc.

b. An unaccusative stratum contains a 2 -arc but no 1-arc.

c. An unergative stratum contains a 1-arc but no 2-arc.

An initially transitive, unaccusative, or unergative clause is one with a transitive, unaccusative, bzw. unergative initial stratum.

The Final 1 Law [Perlmutter and Postal (to appear a)] predicts that (while languages may have clauses with initial or intermediate unaccusative strata), clauses with final unaccusative strata will not be well-formed in any language. Taken together with certain other proposed linguistic universals, 5 this has the following consequence: 
(14) Every clause with an unaccusative stratum involves an advancement to 1 .

Under the Unaccusative Hypothesis, then, initially unaccusative clauses contrast with initially unergative clauses such as

(15) Gorillas play at night.

The simplified relational network for (15) is: (16)

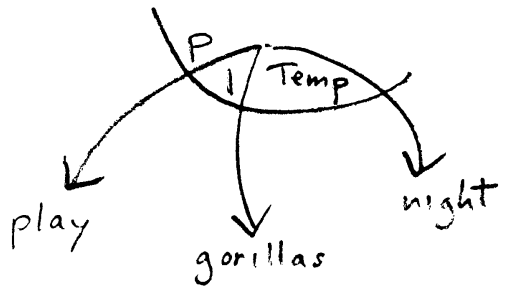

In (16), gorillas does not head a 2-arc, and (16) does not involve an advancement to 1 .

A major question that arises in connection with the Unaccusative Hypothesis is that of the extent to which initial unaccusativity vs. initial unergativity is cross-linguistically uniform and the extent to which it varies from language to language. One can distinguish (at least) three different forms of the Unaccusative Hypothesis.:

(17) a. Initial unaccusativity vs. unergativity varies from language to language. There is no way to predict which clauses in a given language will be initially unergative and which initially unaccusative.

b. There exist principles which predict initial unergativity or initial unaccusativity for a certain class of initially intransitive clauses in all languages. There exists another class of such clauses whose initial unergativity vs. unaccusativity varies from language to language.

c. There exist universal principles which predict initial unergativity vs. unaccusativity for all initially intransitive clauses in all languages. Initial unergativity vs. unaccusativity therefore cannot vary from language to language.

(17c) is obviously the strongest and most interesting hypothesis. It therefore deserves to be tested thoroughly for a variety of languages. The necessary first step is to attempt to formulate the principles predicting initial unergativity vs. unaccusativity on which (17c) must be based.

While I will not attempt to do that here, the basic idea is that initial unergativity vs. unaccusativity is predictable from the semantics of the clause. I limit myself here to 
sketching some of the general factors that seem to play a role in determining initial unergativity vs. unaccusativity, and to giving illustrative examples. While the examples cited are English verbs, the basic idea is that predicates with equivalent meanings in other languages will behave in the same way with respect to determining initial unergativity vs. unaccusativity.

The class of initial unergative clauses seems to correspond closely to the traditional notion of active or activity (intransitive) clauses. These can be broken down into (at least) two subcategories.

(18) Predicates determining initially unergative clauses

a. Predicates describing willed or volitional acts work, play, speak, talk, smile, grin, frown, grimace, think, meditate, cogitate, daydream, skate, ski, swim, hunt, bicycle, walk, skip (voluntary), jog, quarrel, fight, wrestle, box, agree, disagree, knock, bang, hammer, pray, weep, cry, kneel, bow, curtsey, genuflect, cheat, lie (tell a falsehood), study, whistle (voluntary), laugh, dance, crawl, walk, etc. This category includes manner-of-speaking verbs such as whisper, shout, mumble, grumble, growl, bellow, blurt out, etc. and predicates describing sounds made by animals such as bark, neigh, whinny, quack, roar (voluntary), chirp, oink, meow, etc.

b. Certain involuntary bodily processes cough, sneeze, hiccough, belch, burp, vomit, defecate, urinate, sleep, cry, weep, etc.

There may be additional categories as well. Many verbs in English can be used to describe either voluntary or involuntary actions.

The class of predicates determining initial unaccusative strata is very large. These include the following:

(19) Predicates determining initially unaccusative clauses

a. Predicates expressed by adjectives in English

This is a very large class, including predicates describing sizes, shapes, weights, colors, smells, states of mind, etc.

b. Predicates whose initial nuclear term is semantically a Patient

burn, fall, drop, sink, float, slide, slip, glide, soar, flow, ooze, seep, trickle, drip, gush, hang, dangle, sway, wave, tremble, shake, languish, flourish, thrive, drown, stumble, trip, roll, succumb, dry, blow away, boil, seethe, lie (involuntary), sit (involuntary), bend (involuntary), etc. This includes the class of inchoatives, 
including melt, freeze, evaporate, vaporize, solidify, crystallize, dim, brighten, redden, darken, yellow, rot, decompose, germinate, sprout, bud, wilt, wither, increase, decrease, reduce, grow, collapse, dissolve, disintegrate, die, perish, choke, suffocate, blush, open, close, break, shatter, crumble, crack, split, burst, explode, burn up, burn down, dry up, dry out, scatter, disperse, fill, vanish, disappear, etc.

c. Predicates of existing and happening exist, happen, transpire, occur, take place, and various inchoatives such as arise, ensue, result, show up, end up, turn up, pop up, vanish, disappear, etc.

d. Non-voluntary emission of stimuli that impinge on the senses (light, noise, smell, etc.) shine, sparkle, glitter, glisten, glow, jingle, clink, clang, snap (involuntary), crackle, pop, smell, stink, etc.

e. Aspectual predicates

begin, start, stop, cease, continue, end, etc.

f. Duratives

last, remain, stay, survive, etc. [Perhaps these should be considered a subclass of group (c) above.]

Nothing hinges on the particular subcategories given here; alternative classifications are possible.

In developing principles to predict initial unergativity vs. unaccusativity on the basis of meaning, an approach that seems promising is to characterize precisely the class of meanings that determine initial unergative strata, assigning initial unaccustivity to all other initially intransitive clauses.

These lists are offered here as a first step toward constructing explicit principles capable of predicting initial unergativity vs. unaccusativity cross-linguistically. However, one who does not bear in mind that the items in the lists are intended to refer to semantic predicates rather than to verbs of English having a certain phonological shape will almost certainly be misled. Several remarks concerning these lists are therefore in order.

First, many phonological verbs in English can be used both in simple unaccusative clauses and in clauses of another type or types. For example, compare the following sentences with the verb slide:

$\frac{1}{(20)}$ a. The wheels slid on the ice.

b. Joe slid into third base.

c. Joe slid on the ice.

Of these three sentences, only (20a) is unambiguously a simple unaccusative clause. The initial stratum of (20a) contains a 2-arc headed by the wheels. (20b), on the other hand, describes a willed action. Two analyses of it are possible. It 
could have an initial unergative stratum with Joe heading a I-arc, or it could be the causative of an unaccusative clause, with Joe heading a I-arc in the clause whose predicate is CAUSE, and a $2-a r c$ in the clause whose predicate is slide. The choice between these two analyses is irrelevant here. Under either analysis, $(20 \mathrm{~b})$ does not represent a simple unaccusative clause, and therefore it will not behave like one. (20c) is ambiguous. It can describe either a volitional act, in which case it is like ( $20 \mathrm{~b})$, or it can describe a situation in which Joe unwillingly slid on the ice, in which case it is a simple unaccusative clause like (20a). In English it is very common for a single phonological verb to appear in different clause types, as slide does. These examples also illustrate the fact that the distinction between initially unergative and unaccusative clauses does not coincide with the distinction between clauses with animate subjects and those with inanimate ones.

The use of the same phonological verbs in different clause types is quite widespread in English. Consider the following examples :

(2l) a. Marcia fell from the second-story window.

b. Marcia fell right on cue in the second act.

(22) a. The figurine stood on this table.

$b$. The children stood on this table.

(23) a. The needle suddenly jumped six degrees on the dial.

b. The unemployment rate suddenly jumped in July.

c. Henry suddenly jumped over the fence.

$(21 b),(22 b)$, and $(23 c)$ describe willed acts and thus are not simple unaccusative clasues. (2la), (22a), and (23a-b), on the other hand, are unaccusative clauses. Consider also:

(24) a. The train roared as it approached.

b. The lion roared as he approached.

(25) a. The train's wheels hummed as it approached.

b. Henry hummed as he approached.

$(24 b)$ and $(25 b)$ describe willed acts and are initially unergative clauses. (24a) and (25a), on the other hand, are initially unaccusative clauses. 6 Note, for example, that in (24a) the roar is produced by the approach of the train, while in (24b) the roar is not produced by the approach of the lion; the roaring is an additional act.

Second, the lists of predicates given here are far from complete. Certain large classes of verbs, such as verbs of motion, have been omitted entirely because they typically involve ambiguities and the possibilities for alternative analyses similar to those observed with slide.

Third, care must be exercised in making cross-linguistic comparisons because a given verb in one language may not really be equivalent to an apparent synonym in another language. For example, the English verb travel can be used in any of the following sentences: 
(26) a. I like to travel in the summer.

b. The package travelled for two weeks.

c. The shuttle travels back and forth on the loom.

The Dutch verb reizen 'travel', on the other hand, cannot be used in the sense of $(26 b-c)$ :

(27) a. Ik reis graag in de zomer.

b. *Het pakje reisde twee weken.

c. *Het schietspoel reist heen en weer op het getouw.

It is necessary to compare senses or meanings, rather than phonological verb forms.

Despite the practical difficulties that will be encountered in testing the Unaccusative Hypothesis cross-linguistically, however, such work must be done in order to determine which form of the Unaccusative Hypothesis sketched in (17) is to be adopted.

It is instructive to compare the very inadequate attempts made here at describing the semantic difference between initially unergative and unaccusative clauses with descriptions in the literature on other languages where a similar distinction, if not exactly the same one, has been observed. For example, in Dakota [Boas and Deloria (1939)], there are contrasting pronominal forms for the first and second person. While further research must be undertaken to determine whether or not this contrast is determined by the distinction between initial $1 \mathrm{~s}$ and initial $2 \mathrm{~s}$ (in our terms), Boas and Deloria's description is highly suggestive:

There is a fundamental distinction between verbs expressing states and those expressing actions. The two groups may be designated as neutral and active. The language has a marked tendency to give a strong preponderance to the concept of state. All our adjectives are included in this group, which embraces also almost all verbs that result in a state. Thus a stem like "to sever" is not active but expresses the concept of "to be in a severed condition," the active verb being derived from this stem. The same is true of the concept "to scrape," the stem of which means "to be in a scraped condition." Other verbs which we class as active but which take no object, like "to tremble," are conceived in the same way, the stem meaning "to be a-tremble." Active verbs include terms that relate exclusively to animate beings, either as actors or as objects acted upon, such as words of going and coming, sounds uttered by animals and man, mental activities and those expressing actions that can affect only living beings (like to kill, wound, etc.). There seem to be not more than 12 active words that would not be covered by this definition....

The distinction between neutral and active verbs is expressed by the pronoun. As in many American languages, the object of the transitive verb coincides with the subject 
of the neutral verb. In Dakota this may perhaps be so understood that the state is expressed in reference to the person pronoun "being strong is in reference to me;" i.e. "I am strong."

Boas and Deloria's description suggests not only that the distinction between initial $1 \mathrm{~s}$ and initial 2s may determine the choice of contrasting pronominal forms in Dakota, but also that at least some transitive clauses (and perhaps also some unergative clauses) are to be analyzed as complex structures with an embedded unaccusative clause. Research on Siouan languages may produce further evidence for the Unaccusative Hypothesis. Considerable evidence for it has already been amassed, 7 but presentation and discussion of that evidence is beyond the scope of this paper. My goal here is limited to showing that the interaction of the Unaccusative Hypothesis with the 1-Advancement Exclusiveness Law provides an argument for the advancement analysis of impersonal passives over the demotion analysis. This is at the same time an argument for the Motivated Chomage Law.

5. An Empirical Prediction of the Unaccusative Hypothesis, the 1-Advancement Exclusiveness Law, and the Advancement Analysis of Impersonal Passives

The 1-Advancement Exclusiveness Law [Perlmutter and Postal (to appear b)] can be stated informally as follows:

(28) The 1-Advancement Exclusiveness Law

No clause can involve more than one advancement to 1 . Using the notion of 'advancee arc' defined in Perlmutter and Postal (to appear $\mathrm{b}$ ), the law can be stated more precisely:

(29) The 1-Advancement Exclusiveness Law

In a relational network in which $A$ and $B$ are neighboringl-arcs (i.e. l-arcs with the same tail), if $A$ is an advancee arc, $B$ is not an advancee arc.

In $\S 4$ we have seen that under the Unaccusative Hypothesis, all initially unaccusative clauses involve an advancement to 1 .

The 1-Advancement Exclusiveness Law and the Unaccusative Hypothesis, taken together, thus provide a test to distinguish between the advancement analysis and the demotion analysis of impersonal passives. Under the advancement analysis of impersonal passives, the 1-Advancement Exclusiveness Law predicts that impersonal passives of initially unaccusative clauses will be universally impossible. This is because unaccusative clauses necessarily involve an advancement to 1 , and if impersonal passives also involve an advancement to 1 , impersonal passives of initially unaccusative clauses will involve two advancements to 1 , in violation of the 1-Advancement Exclusiveness Law.

In terms of stratal diagrams, under the advancement analysis of impersonal passives, impersonal passives of initially unaccusative clauses would look like: 
(30)

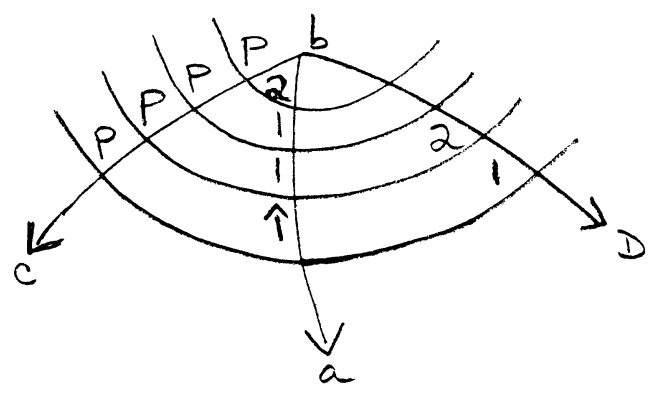

Since (30) involves two advancements to l, such structures will be characterized as ungrammatical by the l-Advancement Exclusiveness Law.

In (30), Unaccusative advancement is in an earlier stratum than Passive. If the dummy bore the 2-relation in the second stratum, advancing to $I$ in the third, the stratal diagram of the relevant relational network would look like:

(3I)

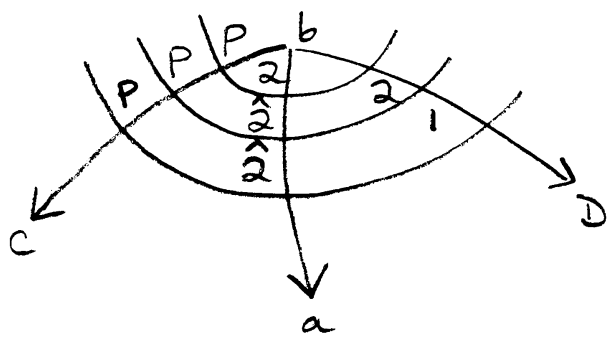

While (3l) does not violate any laws of grammar and therefore is a possible linguistic structure, it is not a Passive structure as characterized in Perlmutter and Postal (1977). The reason is that in the stratum in which the advancee to 1 bears the 2-relation there is no 1. Thus, (31) is an Unaccusative structure and not a Passive structure. Internal to particular languages, (31) will not satisfy the conditions for passive morphology.

Thus under the advancement analysis of impersonal passives, there is no way to have an impersonal passive of an initially unaccusative clause. If the initial unaccusative nominal advances to $l$ in a stratum earlier than the dummy bearing the 2-relation, we get a structure like (30), which violates the 1-Advancement Exclusiveness Law. On the other hand, if the dummy bears the 2 -relation in the second stratum, putting the initial unaccusative nominal en chomage, then the structure in question is not a Passive structure, and so cannot be associated with an impersonal 
passive.

The advancement analysis of impersonal passives, taken together with the Unaccusative Hypothesis and the 1-Advancement Exclusiveness Law, thus predicts that initially unaccusative clauses cannot have impersonal passives. The demotion analysis makes no such prediction. If the prediction is correct, it will be an argument for the advancement analysis of impersonal passives. Further, since the Motivated Chomage Law is incompatible with the demotion analysis of impersonal passives and requires the advancement analysis of impersonal passives, any argument for the advancement analysis is an argument for the Motivated Chomage Law as well. A linguistic theory incorporating the Motivated Chomage Law, in conjunction with the Unaccusative Hypothesis, the 1-Advancement Exclusiveness Law, and the advancement analysis of impersonal passives, predicts the ungrammaticality of impersonal passives of initially unaccusative clauses.

6. The Evidence from Dutch

Dutch is a particularly good language for which to illustrate the prediction brought out in $\$ 5$. This is because unlike many other languages, Dutch allows the Passive chomeur to appear overtly in impersonal passives. The Dutch data thus enables one to see more clearly that the grammaticality or ungrammaticality of impersonal passives depends on initial unergativity vs. unaccusativity, which in turn depends on the semantic relation the initial nuclear term bears in the clause; a mere listing of predicates would not suffice to characterize the difference.

The following examples illustrate the grammaticality in Dutch of impersonal passives of initially unergative clauses:

(32) Er wordt hier door de jonge lui veel gedanst. 'It is danced here a lot by the young people.'

(33) Er wordt voor de koning geknield. 'It is kneeled before the king.'

(34) Hier wordt (er) veel gewerkt. 'It is worked here a lot.'

(35) Er wordt in deze kamer vaak geslapen. 'It is often slept in this room.'

(36) Over dit problem wordt er vaak gesproken/gepraat/gedacht. 'About this problem it is often spoken/talked/thought.'

(37) Door deze mensen wordt er altijd gevochten. 'By these people it is always fought.'

(38) Er wordt hier veel geskied. 'It is skied here a lot.' 
(39) Er wordt geblaft/gehinnikt/gekrast/gemiauwd.

'It is (being) barked/whinnied/crowed/meowed.'

(40) Er wordt gehuild.

'It is (being ) cried/howled.'

(41) Er wordt op de deur geklopt.

'It is (being) knocked on the door.'

(42) Er wordt geniesd/gehoest/gehikt.

'It is (being) sneezed/coughed/hiccoughed.'

(43) Er wordt gebeden.

'It is (being) prayed.'

(44) Er wordt geschreeuwd/gemompeld/gemumeld/gefluisterd.

'It is being screamed/grumbled/mumbled/whispered.'

(45) Door de kinderen wordt altijd gelachen.

'By the children it is always laughed.'

(46) Door de jonge lui wordt er nu vaak gemediteerd. 'By the young people it is now often meditated.'

(47) Door jonge meisjes wordt (er) vaak gedagdroomd. 'By young girls it is often daydreamed.'

(48) Er wordt door de kinderen in de tuin heen en weer gerend.

'It is run back and forth in the garden by the children.'

(49) Er wordt door hem altijd gedubd. 'It is always thought deeply by him.

(50) Er wordt door de kinderen nog niet gerookt.

'It is not yet smoked by the children.'

Just as predicted, initially unaccusative clauses do not have well-formed impersonal passives. In each case a grammatical active unaccusative sentence is cited, followed by the corresponding impersonal passive, which is ungrammatical.

(51) a. De lijken zijn al gerot/ontbonden.

'The corpses have already rotted/decomposed.'

b. *Door de lijken werd al gerot/ontbonden.

(52) a. In dit weeshuis groeien de kinderen erg snel.

'In this orphanage the children grow very fast.'

b. *In dit weeshuis wordt er door de kinderen erg snel gegroeid.

(53) a. Het water was binnen een kwartier verdampt.

'The water had evaporated in a quarter hour.'

(54) *Er werd door het water binnen een kwartier verdampt.
a. De kinderen zijn in Amsterdam gebleven. 'The children remained in Amsterdam.'

(55) b. *Er werd door de kinderen in Amsterdam gebleven.

a. Het concert heeft een hele tijd geduurd. 'The concert lasted a long time.'

b. *Er werd door het concert een hele tijd geduurd. 
(56) a. Zijn moeder alleen overleefde.

'Only his mother survived.'

b. *Er werd alleen door zijn moeder overleefd.

(57) a. Het water sijpelde/drippelde uit de rots. 'The water seeped/dripped out of the rock.'

b. *Er werd door het water uit de rots gesijpeld/ gedrippeld.

(58) a. Het water gutste uit de kraan. 'The water gushed from the tap.'

b. *Er werd door het water uit de kraan gegutst.

(59) a. Een heleboel bommen zijn gisteren ontploft in Belfast.

'A lot of bombs exploded yesterday in Belfast.'

b. *Er werd gisteren door een heleboel bommen ontploft in Belfast.

(60) a. De bloemen waren binnen een paar dagen verflenst. 'The flowers had wilted in a few days.'

b. *Er werd door de bloemen binnen een paar dagen verflenst.

(61) a. Vele kinderen verdwijnen uit dit weeshuis. 'Many children disappear from this orphanage.'

b. *Uit dit weeshuis wordt (er) door vele kinderen verdwenen.

(62) a. Vele kinderen zijn in de rook gestikt. 'Many children suffocated in the smoke.'

b. *Er werd door vele kinderen in de rook gestikt.

(63) a. De grassprietjes zijn vannacht ontsproten.

'The grass sprouts sprouted last night'

b. *Er werd door de grassprietjes vannacht ontsproten.

(64) a. De kinderen bungelden aan de kabel.

'The children dangled from the cable.'

b. *Er werd door de kinderen aan de kabel gebungeld.

(65) a. Zulke dingen zijn hier nooit gebeurd.

'Such things have never happened here.'

b. *Hier werd er door zulke dingen nooit gebeurd.

(66) a. Dat blok hout heeft goed gebrand. 'That block of wood burned well.'

b. *Er werd door dat blok hout goed gebrand.

(67) a. In dit ziekenhuis sterven de patienten dikwijls.

'In this hospital the patients often die.'

b. *In dit ziekenhuis wordt (er) door de patienten dikwijls gestorven.

There are some close contrasts that illustrate the relevance of the unergative-unaccusative distinction in predicting the status of impersonal passives. Consider the following:

(68) a. In de zomer wordt er hier vaak gezwommen. 'In the summer it is swum here frequently.' 
b. *In de zomer wordt er hier vaak verdronken.

'In the summer it is drowned here frequently.' Zwemmen 'swim' describes a willed activity. It therefore has an initial unergative stratum and allows impersonal passives. Verdrinken 'drown,' on the other hand, describes not a willed activity, but something in which the initial nuclear term is semantically a Patient. It thus determines an initial unaccusative stratum and, as predicted, does not allow impersonal passives. Similarly, if the verb glijden 'slide' describes a willed activity, the initial stratum is unergative and an impersonal pasive is possible:

(69) a. De kinderen hebben lekker op het ijs gegleden. 'The children enjoyed sliding on the ice.'

b. Er werd door de kinderen lekker op het ijs gegleden. But forms of glijden where the final 1 is a Patient rather than an Actor (and hence determines an initial unaccusative stratum), as predicted, do not allow impersonal passives:

(70) a. De sneeuw is van het dak afgegleden.

'The snow slid off the roof.'

b. *Er werd door de sneeuw van het dak afgegleden.

Another illustration of the predicted status of impersonal passives is the fact that if a native speaker of Dutch is presented with an impersonal passive of a sentence with an initial unaccusative stratum, he or she will either reject it outright, or else try to render it interpretable by imputing an activity reading to it. In this connection, consider * (7Ib), the impersonal passive of (7la).

(71) a. De krengen stonken vreselijk.

'The carcasses smelled terribly.'

b. *Er werd door de krengen vreselijk gestonken. As predicted, *(71)b) is ungrammatical as a paraphrase of (7la). However, a speaker may give it an interpretation in the following way. Kreng is also a pejorative term something like 'bitch.' Thus, * (7lb) applied to women, mean something like: 'The bitches stank terribly, intentionally emitting foul odors.' The key point is that the meaning of intentionality attributed to $*(71 \mathrm{~b})$ makes it an activity clause describing a volitional act, and hence a clause with an initial unergative stratum, as required by the theory of impersonal passives defended here.

There are examples that show that the status of the impersonal passive cannot be characterized merely by giving lists of predicates. The contrasts observed are precisely the kinds of contrasts associated with the difference between unergative and unaccusative initial strata cross-linguistically. In each case, the (a)-sentence describes a willed action which accordingly determines an initial unergative stratum. The corresponding impersonal passive in the (b)-sentence is grammatical. The (c)-sentence, 
however, though constructed with the same verb, does not describe a willed action and consequently has an initial unaccusative stratum. As predicted, the corresponding impersonal passive in the (d)-sentence is ungrammatical.

(72) a. De edelen buigen voor de koning. 'The nobles bend (bow) before the king.'

b. Er wordt door de edelen voor de koning gebogen.

c. De bloemen buigen in de wind. 'The flowers bend in the wind.'

d. *Er wordt door de bloemen in de wind gebogen.

(73) a. De kinderen staan altijd op deze tafel wanneer zij uit het raam willen kijken.

'The children always stand on this table when they want to look out the window.'

b. Op deze tafel wordt (er) altijd door de kinderen gestaan wanneer zij uit het raam willen kijken.

c. Het beeldje staat altijd op deze tafel. 'The figurine always stands on this table.'

d. *op deze tafel wordt (er) altijd door het beeldje gestaan.

(74) a. De nieuwe acteur is in het tweede bedrijf op het juiste ogenblik gevallen.

'The new actor fell at the right moment in the second act.'

b. In het tweede bedrijf werd er door de nieuwe acteur op het juiste ogenblik gevallen.

c. Twee mensen zijn uit de venster van de tweede verdieping gevallen.

'Two people fell out of the second-storey window.'

d. *Er werd door twee mensen uit de venster van de tweede verdieping gevallen.

(75) a. Het publiek murmelde gedurend het concert. 'The audience murmured during the concert.'

b. Er werd door het publiek gedurend het concert gemurmeld.

c. Het beekje murmelde zachtjes. 'The brook murmured gently.'

d. $*$ Er werd door het beekje zachtjes gemurmeld.

Examples like this not only support the hypothesis defended here, they also illustrate some of the difficulties that will allow an overt chomeur in impersonal passives. For such languages, if one simply presents a speaker with an impersonal passive such as

(76) Er werd gevallen.

'It was fallen.'

and if the hypothesis presented here is correct, the speaker will react differently, depending on whether he has in mind a context like $(74 b)$ or one like $*(74 d)$. Thus, if such a pro- 
cedure is followed, the data obtained will show great variation from one speaker to another and with the same speaker from one occasion to another. It is necessary to take into account the semantic factors that determine initial unergativity vs. unaccusativity to obtain a true test of the predictions for other languages of the hypothesis presented here.

7. Argument against a Characterization of Passive in

\section{Semantic Terms.}

The proposal defended here characterizes Passive structures - both personal and impersonal - in syntactic terms, as proposed in Perlmutter and Postal (1977). Pains have been taken, however, to give evidence that the assignment of initial termhood depends on semantic factors. The question might then arise as to why Passive structures should be characterized in syntactic, rather than semantic, terms. For example, it might be proposed that the contrast between grammatical and ungrammatical impersonal passives brought out in $\S 6$ can be incorporated into a grammar of Dutch by stating Passive in semantic terms along the lines of one of the statements in:

(77) a. A passive construction is possible only if the initial 1 is semantically an Agent.

b. A passive construction is possible only if the clause describes a willed or volitional act, or certain involuntary bodily processes.

While such statements may describe the situation for impersonal passives in Dutch, there are numerous examples of personal passives where these conditions are not met:

(78) Dat wordt door bijna iedereen geloofd/verstaan/ verondersteld/voorondersteld/betwijfeld/vermoed. 'That is believed/understood/assumed/presupposed/ doubted/suspected by almost everyone.'

(79) Zij wordt door iedereen gehaat/veracht/bewonderd/ geacht/gerespekteerd.

'She is hated/despised/admired/respected by everyone.'

(80) Hij wordt door zijn kollega's als incompetent beschouwd.

'He is considered incompetent by his colleagues.'

(81) Zijn verwaandheid wordt alleen door zijn algemene onaangenaamheid overtroffen.

'His arrogance is exceeded only by his general unpleasantness.'

(82) Deze hypotese wordt door de feiten weerlegd/ bevestigd/gesteund.

'This hypothesis is refuted/confirmed/supported by the facts.'

(83) Ik werd aan zijn verdwijning herinnerd door een kort nieuwsberichtje op pagina 5 . 
'I was reminded of his disappearance by a short news item on page $5 . '$

(84) De klasse van grammatikale zinnen wordt gekenmerkt door een set voorwaarden op goedgevormde relationele netwerken.

'The class of grammatical sentences is characterized by a set of conditions on well-formed relational networks.'

(85) De situatie werd verergerd door een verhoogde afhankelijkheid van buitenlandse petroleum. 'The situation was exacerbated by increased dependence on foreign oil.'

(86) Zijn positie is door de recente ontwikkelingen ondermijnd geworden.

'His position has been undermined by the recent developments.'

(87) Het dak wordt door stalen palen geschut. 'The roof is supported by steel columns.'

(88) Het huis wordt door hoge elmen omringd. 'The house is surrounded by tall elms.'

(89) Hij werd door een gevoel van hopeloosheid overvallen. 'He was overcome by a feeling of hopelessness.'

(90) De brief werd door de geadresseerde niet ontvangen. 'The letter was not received by the addressee.'

(91) Dat ze loog werd door de jury aangevoeld. 'That she was lying was sensed by the jury.'

The initial Is in these examples have a variety of semantic roles - Experiencer, Cognizer, Recipient, and others whose nature remains obscure. Both attempted characterizations in (77) fail.

Of course, one might adopt one of the characterizations in (77) only for impersonal passives, and deal with personal passives in a different way. There are two arguments against this.

First, it would miss the generalization uniting personal and impersonal passives, needlessly complicating the grammar with two separate characterizations where one suffices. Internal to the grammar of Dutch, it would complicate the rules that are responsible for passive morphology on the verb and the marking of the chomeur with door.

Second, the characterizations in (77), if properly stated, would duplicate the statement that is needed independently to assign initial unergative strata. While limitations of space here make it impossible to show that the distinction between unergative and unaccusative clauses accounts for many other syntactic phenomena, 8 each such demonstration will add to the evidence that an ad hoc characterization like one of those in (77), for impersonal passives alone, is unnecessary . 
8.

Conclusions for the Grammar of Dutch and Universal Grammar

What must be stated in the grammar of Dutch to account for the data on impersonal passives presented here? Under the proposal advanced here, the grammar of Dutch needs only:

(92) a. a statement that impersonal passives of intransitive clauses are possible in Dutch.

b. a rule stating the conditions under which the dummy appears in the surface string.

Passive morphology on the verb and marking of the chomeur with door are accounted for by the same rules that are needed for personal passives. The conditions governing (92b) in two varieties of Dutch have been studied by Maling and Zaenen (to appear), and will not concern us here. ${ }^{9}$

The contrasts between grammatical and ungrammatical impersonal passives presented here follow entirely from principles of universal grammar. They are:

(93) a. the universal advancement analysis of impersonal passives imposed by the Motivated Chomage Law

b. the predictability of initial unergative vs. unaccusative strata in accordance with the strong version of the Unaccusative Hypothesis sketched in (17c)

c. the l-Advancement Exclusiveness Law

d. the Final 1 Law, the Relational Succession Law, and the Active Dummy Law, which together ensure that every clause with an unaccusative stratum involves an advancement to 1 (cf. fn.5) 10

Each of these proposed linguistic universals is motivated by data that has nothing to do with impersonal passives. The fact that they predict the contrasts between grammatical and ungrammatical impersonal passives in Dutch thus provides an explanation of those contrasts. At the same time, the Dutch data provides empirical support for the principles of universal grammar in (93).

This situation can be contrasted with that in a grammar of Dutch that incorporates the demotion analysis of impersonal passives. Such a grammar would have to include some ad hoc device to account for the contrast between those intransitive clauses that have grammatical impersonal passives and those that do not. Whatever the nature of that device, it would have to treat clauses with initial unergative strata differently from those with initial unaccusative strata, presumably stating a constraint preventing the demotion of ls in clauses with initial unaccusative strata. Such a constraint, however, is completely superfluous, since under the advancement analysis of impersonal passives the ungrammaticality of impersonal passives of such clauses is a consequence of universal prin- 
ciples of grammar. The failure of the demotion analysis lies in its inability to make the ungrammaticality of such impersonal passives follow directly from universal principles.

9. Evidence from Turkish

The claim that the ungrammaticality of the impersonal passives of initially unaccusative clauses in Dutch follows from universal principles of grammar entails that the same will be true of the corresponding sentences in every language that has impersonal passives. I will illustrate this briefly with data from Turkish. More extensive testing of the hypothesis presented here must be carried out for other languages.

Two factors have dictated the choice of Turkish as an illustrative language. First, since it is a non-IndoEuropean language, the similarity to Dutch cannot be attributed to genetic relationship. Second, the explanation offered here for the ungrammaticality of impersonal passives of initially unaccusative clasues rests on the advancement of a dummy from 2 to 1 . Unlike Dutch, however, Turkish never has dummies appearing in the surface string. On these grounds alone, some linguists would deny that dummies play a role in Turkish sentence structure. It is claimed here, however, that dummies play exactly the same role in impersonal passives in Turkish that they do in Dutch. The only difference is in the conditions under which these dummies are realized on the surface. As Maling and Zaenen (to appear) show, these conditions for Dutch differ dialectally and involve certain complications. For Turkish, however, the generalization is very easy to state:

(94) No dummies appear overtly in Turkish sentences. With this generalization incorporated in the grammar of Turkish, the surface distribution of dummies in Turkish is accounted for.

Since Turkish has many sentences (including impersonal passives) with no overt subject in the surface string, it is also superficially a counterexample to the Final 1 Law. As noted in Perlmutter and Postal ( to appear a), many languages superficially appear to violate this law. The question is whether more detailed analysis of the languages in question will provide evidence for final ls that do not appear overtly. In providing evidence for dummies as final Is in Turkish impersonal passives, the present paper contributes to the evidence for the Final 1 Law.

Initial unergative clauses in Turkish have grammatical impersonal passives:

(95) Burada Galıईılır/oynanır/bağırılır.

'Here it is worked/played/shouted.'

(96) Burada sik sik yilksek sesle konuşulur.

'Here it is often spoken with a high voice.'

(97) Burada sik sik kavga edilir.

'Here it is often fought.' 
(98) Burada gecenin ges saatlerine kadar dans edilir. 'Here it is often danced until the late hours of the night.'

(99) Burada mızlkgılık edilmez.

'Here it is not cheated.'

(100) Düşmandan kaçı Imaz.

'From the enemy it is not run away.'

Passive chomeurs cannot appear overtly in Turkish impersonal passives.

As predicted, impersonal passives of initially unaccusative clauses are ungrammatical.

(101) *Buharlas lldı/çüründü/kokuldu.

'It was evaporated/rotted/smelled.'

(102) *Damlanır/fişkirilir.

'It is dripped/gushed.'

(103) *Buzun üstünde sik sik dúşưlur.

'It is often fallen on the ice.'

(104) *Yazın burada boğulunur.

'In the summers here it is drowned.'

(105) *Sonbaharda sararilır.

'In the fall it is yellowed.'

(106) *Sonbaharda kurunur.

'In the fall it is become dry.'

(107)*Bu yetimhanede çabuk büyünür.

'In this orphanage it is grown fast.'

(108) *Bu gibi durumlarda ölunir.

'In such situations it is died.'

There are also some close contrasts illustrating the difference between initially unergative and unaccusative clauses.

(109) a. Bu hapishaneden sık sık kaçılır.

'From this prison it is often run away.'

b. *Bu hapishaneden $\mathrm{s} \mathfrak{k}$ sık kaybolunur.

'From this prison it is often disappeared.'

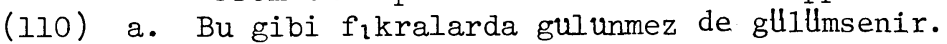

'At such jokes it is not laughed but smiled.'

b. *Bu gibi fikralarda kızarılır.

'At such jokes it is blushed.'

The verb kaymak means 'slip' or 'slide,' and is generally used to describe an involuntary action; the initial nuclear term in kaymak clauses in this use is consequently a Patient and the clauses are initially unaccusative. However, kayak kaymak means 'ski,' a willed activity, and therefore determines initially unergative strata. This difference between kaymak and kayak kaymak results in the predicted contrast in impersonal passives:

(III) a. Burada kayak kayılır.

'Here it is skied.'

b. *Burada kayılır.

'Here it is slipped/slid.' 
Limitations of space here prevent a thorough survey of the possibilities of impersonal passives in Turkish. The data presented is exactly what is predicted by the hypothesis defended here. It thus provides further support for the universals in (93). The grammar of Turkish needs only:

(112) a. a statement that impersonal passives of intransitive clauses are allowed.

b. the constraint that disallows a Passive chomeur to appear overtly in an impersonal passive.

c. a statement of the generalization in (94). Everything else follows from the principles of universal grammar in (93). (1lla) is associated with a relational network that can be abbreviated in simplified form as the following stratal diagram:

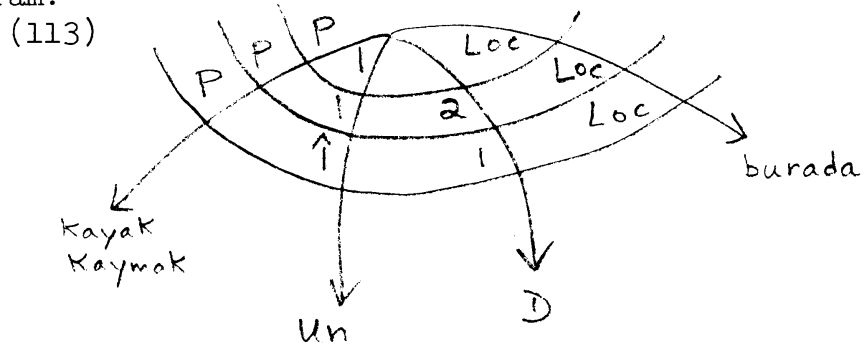

As in Dutch and other languages, impersonal passives in Turkish involve the advancement of a dummy from 2 to 1 . The passive morphology in impersonal passives follows from the rules that are needed independently for personal passives. By predicting the contrasts in grammaticality between impersonal passives of initially unergative vs. unaccusative clauses in Turkish, the principles of universal grammar in (93) explain them. At the same time, these contrasts provide further empirical support for those universal principles.

10. A further Prediction: Interaction of Passive and Inversion The predictions of the hypothesis presented here for impersonal passives stem from two things:

(114) a. Clauses with an unaccusative stratum necessarily involve an advancement to 1 .

b. Impersonal passives involve an advancement to $l$. Given (114a-b), the 1-Advancement Exclusiveness Law predicts the ungrammaticality of impersonal passives of clauses with an unaccusative stratum.

The only unaccusative clauses we have been concerned with so far are those whose initial stratum is unaccusative. However, there are also clauses with non-initial unaccusative strata. Initially transitive Inversion clauses are of this type. 
In the Inversion construction, a nominal that heads a 1-arc in one stratum heads a 3-arc in the next. Thus, a partial relational network for initially transitive Inversion clauses is the following:

(115) a.

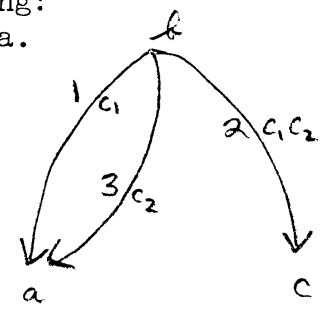

$\mathrm{b}$.

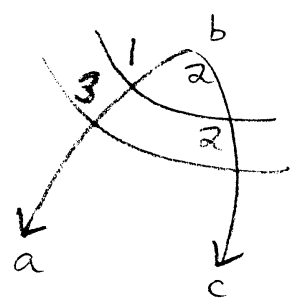

In (115), while the first stratum is transitive, the second is unaccusative. Like initially unaccusative clauses, such Inversion clauses necessarily involve an advancement to 1 , for the same reasons. Thus, under the advancernent analysis of impersonal passives, the 1-Advancement Exclusiveness Law predicts that impersonal passives of Inversion clauses will be ungrammatical.

We will not be concerned here with evidence for the demotion of a 1 to a 3 in the Inversion construction. A considerable amount of such evidence has already been amassed. II The only point of interest here is the prediction of the 1-Advancement Exclusiveness Law that Inversion clauses cannot have passives whether personal or impersonal. Although Dutch and Turkish are not among the languages for which Inversion has been motivated in detail, I will illustrate the prediction with Dutch and Turkish examples.

Consider first the Dutch sentence

(116) Dat detail ontsnapt iedere keer aan onze voorzitter.

'That detail escapes our chairman every time.' Dat detail is the final 1 of (116), and onze voorzitter 'our chairman' is marked with the preposition aan, which marks final $3 \mathrm{~s}$ in Dutch. Under an Inversion analysis, the relational network associated with (116) can be abbreviated as the following stratal diagram: 12

(117)

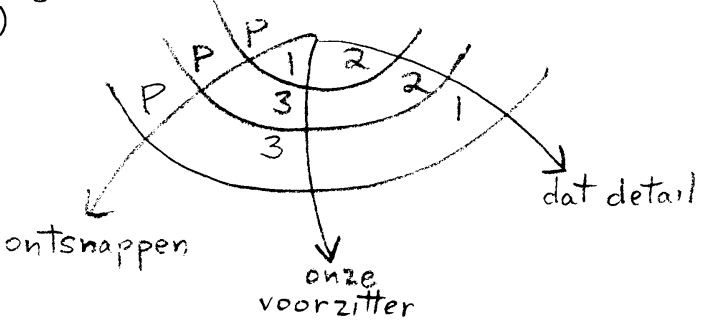


(117) has an unaccusative second stratum and advancement of the initial 2 to 1. As predicted, no grammatical impersonal passive of (116) can be constructed:

(118) a. *Er wordt aan onze voorzitter door dat detail iedere keer ontsnapt.

b. *Aan onze voorzitter wordt (er) door dat detail iedere keer ontsnapt.

c. *Door dat detail wordt (er) aan onze voorzitter iedere keer ontsnapt.

The impossibility of *(118), a consequence of the 1-Advancement Exclusiveness Law, thus supports the Inversion analysis of (116) in (117).

3-2 Advancement is productive in Dutch, 13 and there is another grammatical sentence in which onze voorzitter, a final 3 in (116), has advanced to 2 :

(119) Dat detail ontsnapt onze voorzitter iedere keer. 'That detail escapes our chairman every time.' In (119), onze voorzitter is not marked with aan and immediately follows the verb, as other final 2s do. Thus, the simplified network I propose for (119) is:

(120)

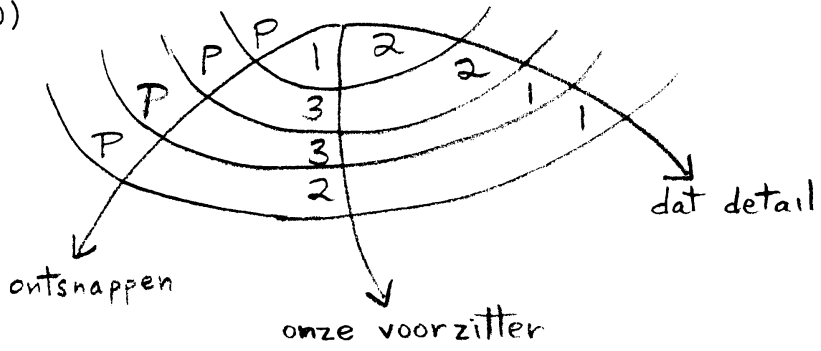

Like (117), (120) involves an advancement to 1. Thus, although onze voorzitter is final 2 in (119/120), the l-Advancement Exclusiveness Law predicts the ungrammaticality of a personal passive:

(121) * Onze voorzitter wordt door dat detail iedere keer ontsnapt.

Under the same analysis (involving Inversion and 3-2 Advancement) of the English sentences

(122) a. Those details escape me every time.

b. Those details elude me every time.

the 1-Advancement Exclusiveness Law predicts the ungrammaticality of the corresponding passives:

(123) a. *I am escaped by those details every time.

b. *I am eluded by those details every time.

Turning now to Turkish, I propose an Inversion analysis for sentences such as: 

(124) Bu imtihan bana zor geldi. this test me difficult came
(125) This test was difficult for me.' $\mathrm{Bu}$ bana yeter.
This me/DAT sufficient+AOR
'This is sufficient for me.'

Under this analysis, the network associated with (124) can be abbreviated as: ${ }^{14}$

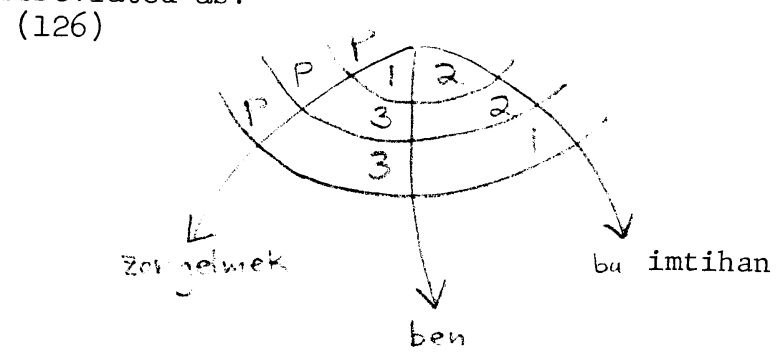

Since (126) involves an advancement to l, the l-Advancement Exclusiveness Law predicts the ungrammaticality of impersonal passives:

(127) *Bana zor gelindi.

(128) *Bana yetilir.

Note that the impossibility of impersonal passives of Inversion clauses, which are superficially intransitive with a final 3, contrasts with the grammaticality of the impersonal passives of other intransitive clauses with $3 \mathrm{~s}$ :

(129) Bu adama sik sik telefon edilir. 'To this man it is often telephoned.'

(130) Hasana yardım edildi. 'To Hasan it was helped.'

Under the Inversion analysis of (124-125), this contrast is a consequence of the l-Advancement Exclusiveness Law. The fact that the law accounts for the ungrammaticality of the impersonal passives constitutes evidence for the Inversion analysis.

11. A Universal Characterization of Passive Clauses

The analysis of impersonal passives defended here brings them under the rubric of the universal characterization of passivization proposed in Perlmutter and Postal (1977). Ignoring the additional complications involved in reflexive passives (both personal and impersonal), passive clauses can be characterized as universally involving relational subnetworks of the form: 

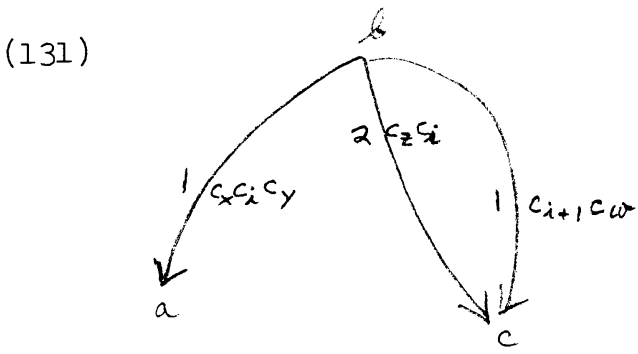

Impersonal passives differ from personal passives in that the nominal heading a 2 -arc and a 1 -arc in successive strata is a dummy. In many languages, as in Dutch and Turkish, impersonal passives are morphologically like personal passives. This is accounted for in grammars of those languages in which the rules responsible for the morphology simply refer to subnetworks of the form (131). However, it is not excluded that personal and impersonal passives could differ morphologically in some languages. Any such differences would be accounted for by grammars in which the relevant morphological rules are sensitive to whether or not the nominal heading a 2-arc and 1-arc in successive strata is a dummy. Since this requires an extra specification in the relevant morphological rules, it is likely that languages with such morphological differences between personal and impersonal passives will be in the minority, but nothing in the proposal presented here excludes them from the class of possible languages.

Any syntactic differences between personal and impersonal passives in particular languages can be stated in their grammars in the same way. As with morphological differences, any such syntactic differences require explicit statement. Under the proposal for impersonal passives advanced here, then, they will be like personal passives in a particular language unless something in the grammar specifies otherwise. This means that there will be a tendency across languages for personal and impersonal passives to be alike in various ways, but no requirement that they be. This proposal thus includes within the class of possible languages languages in which personal and impersonal passives differ in various ways.

The grammars of languages such as English, which do not have impersonal passives, must state that in subnetworks of the form ( 131 ), $c$ cannot be a dummy. The grammars of languages that have impersonal passives but no personal ones must state that in subnetworks of the form (131), c must be a dummy. The grammars of languages that do not have passives at all must state that relational networks with subnetworks of the form 
(131) are ill-formed in those languages. In the grammars of many languages, conditions of these kinds will also have to be stated for particular predicates or classes of predicates, since predicates within a given language can differ with respect to whether or not they allow passives, and if so, what type.

The inclusion of impersonal passive constructions with passives does not change the universal characterization of passive clauses proposed in Perlmutter and Postal (1977). In conjunction with other universals proposed there such as the Stratal Uniqueness Law and the Chomeur Law, the following are then universals of passive clauses:

(132) Universals of passive constructions

a. The passive construction involves two successive strata, the first of which I will call the 'departure stratum' and the second the 'arrival stratum.'

b. The departure stratum is transitive.

c. The arrival stratum is unergative.

d. The nominal that heads the 2-arc in the departure stratum heads the l-arc in the arrival stratum.

Under the interpretation of the formalism of relational networks, (132) entails that passivization involves two linguistic levels, with a $l$ and a 2 at the first level, but only a 1 (and nc 2 ) at the second level. The nominal that bears the 2-relation at the first level bears the l-relation at the second level.

Given the proposed universal characterization of passivization, properties of passivization such as the following are hypothesized to vary from language to language:

(133) a. Verb morphology in Passive clauses

b. Marking of Passive chomeurs

c. Ability of Passive chomeurs to appear in surface strings

d. Interaction of the Passive construction with language-particular constraints on definiteness, animacy, specificity, etc.

e. Interaction of the Passive construction with hierarchies of person, animacy, etc.

$f$. Interaction of the Passive construction with discourse-conditioned and/or pragmatic conditions

g. Restrictions on tense, aspect, mood, morphological class of verb, etc.

The passive construction also interacts with languageparticular rules and conditions governing agreement, reflexivization, case marking, word order, and many other grammatical 
phenomena, so that a list like that in (133) could be continued.

Under the characterization of impersonal passives defended in this paper, they are passives and therefore are predicted to be cross-linguistically uniform in the ways listed in (132) and to vary in the ways listed in (133). In addition, impersonal passives can vary from language to language in two ways that are not relevant for personal passives:

(134) a. Whether or not they are restricted to transitive or to intransitive clauses.

b. The conditions under which the dummy that advances from 2 to 1 appears in the surface string.

12. Conclusions

The basic empirical result of this paper can be simply stated:

(135) No clause with an unaccusative stratum can have a passive.

Since (135) was shown to follow from principles of grammar proposed as linguistic universals, data from any language could show (135) to be false. That would make it necessary to modify or abandon at least one of the universals that jointly predict (135).

(135) has a number of particular consequences that will be enumerated briefly below.

Most clauses with an unaccusative stratum are also intransitive in all succeeding strata. Most of the concrete predictions brought out in this paper therefore concern impersonal passives. Most of this paper has been devoted to showing that clauses whose initial stratum is unaccusative cannot have impersonal passives. In $\$ 10$ it was shown that the same is true of Inversion clauses, which have a noninitial unaccusative stratum. Both of these points were illustrated with data from Dutch and Turkish. Their import, however, is universal.

In $\$ 10$ another consequence of (135) was pointed out that superficially transitive clauses involving Inversion and 3-2 Advancement cannot have personal passives. This was illustrated with data from Dutch and English.

The fact that clauses with unaccusative strata cannot have impersonal passives was used here as an argument in favor of the advancement analysis of impersonal passives over the "spontaneous chomage" or demotion analysis. Under the advancement analysis of impersonal passives, the ungrammaticality of impersonal passives of clauses with unaccusative strata follows from the 1-Advancement Exclusiveness Law (and the other proposed universals mentioned).

The results obtained here illustrate the predictive power (and hence heuristic value) of linguistic universals. A 
small set of proposed universals was shown to make certain empirical predictions, and these predictions were shown to be confirmed for Dutch and Turkish. Thus, the fact that impersonal passives such as

(136) *In Belfast wordt (er) vaak ontploft. 'In Belfast it is frequently exploded.'

and

(137) *Belfastta sık sık infilâk edilir.

'In Belfast it is frequently exploded.'

are ungrammatical in these two languages is not an accident, but a consequence of universal principles of grammar.

The fact that a large class of intransitive verbs cannot have impersonal passives has not to my knowledge even been systematically noted before. Traditional grammars of languages with impersonal passives typically mention the fact that intransitive verbs can have passive forms, give a few examples, and leave the matter at that. Since such grammars typically do not even note that many intransitive clauses cannot have impersonal passives, the question of characterizing the difference between those that can and those that cannot does not even arise. One of the aims of this paper has been to give a preliminary characterization, inadequate though it may be, of the semantic factors that determine initial unergativity vs. unaccusativity and hence the possibility of impersonal passives. Another has been to make explicit the prediction that, under the strongest version of the Unaccusative Hypothesis sketched in (17c), this characterization will also be relevant for many other syntactic phenomena.

\section{Footnotes}

*This work was supported in part by the National Science Foundation through Grant No. BNS 76-00764 to the Massachusetts Institute of Technology and the John Simon Guggenheim Memorial Foundation through a Guggenheim Fellowship.

I am greatly indebted to Hans den Besten, Jaklin Kornfilt, and especially Annie Zaenen for their willingness to construct examples and test them against their native intuitions. The Unaccusative Hypothesis itself developed in joint work with Paul Postal, who contributed to the ideas developed here in many ways. Responsibility for errors and inadequacies in this paper is my own.

1. Breckenridge (1975) provides strong arguments for treating passives and impersonal passives in the same way. 2. For an explanation of the notation of stratal diagrams, see Perlmutter and Postal (1977). 
3. Impersonal passives of transitive clauses (in the langua.ges that allow them) also involve advancement of a dummy from 2 to 1 , yielding relational networks that can be represented as stratal diagrams of the following form:

(i)

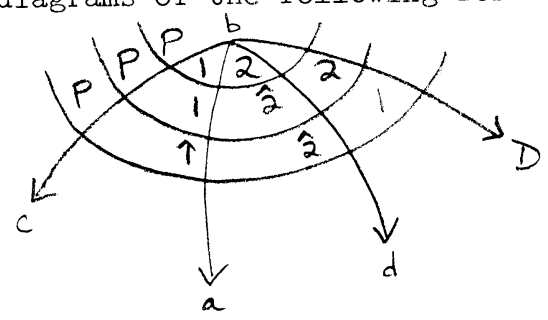

Impersonal passives of transitive clauses are ignored in this paper.

4. The terms 'unaccusative' and 'unergative' are due to Geoffrey Pullum.

5. The relevant universals are the Relational Succession Law [Perlmutter and Postal (to appear c)] and the Active Durmy Law [Perlmutter (in prep. a)]. As a consequence of the Relational Succession Law, an ascendee cannot assume the l-relation unless the host out of which it ascends is also a 1. Thus, an unaccusative stratum cannot be immediately followed by a stratum with a l-arc as a consequence of an ascension. As a consequence of the Active Dummy Law, an unaccusative stratum in which a nominal other than a dummy heads a 2-arc cannot be immediately followed by a stratum in which a dummy heads a 1-arc.

6. For evidence distinguishing unergative and unaccusative clauses in English, see Perlmutter and Postal (to appear b), Perlmutter (in preparation c), and especially Postal (in preparation).

7. See Harris (to appear c), Perlmutter (in preparation b), and the references in footnote 6 . Some of the data adduced by Uhlenbeck (1916) led Sapir (1917) to suggest a form of the Unaccusative Hypothesis for certain Amerindian languages. There is much that bears on the Unaccusative Hypothesis in these two works. While Sapir was to my knowledge the first to suggest the Unaccusative Hypothesis in any form, his proposal differs from that given here and in the references cited in footnote 6 in several respects. First, Sapir suggested it as one of two possible analyses, and then only for certain languages. Thus, he essentially proposed it as the basis for a typological distinction among languages. The current relational grammar proposal, on the other hand, is that the existence of unaccusative clauses is a linguistic universal. Second, we differ from Sapir with respect to which clauses 
are assigned to which clause type (unergative vs. unaccusative) in certain cases.

8. But cf. the references in footnotes 6 and 7 .

9. I ignore here the many semantic, pragmatic, and stylistic factors governing felicitous use of passives in Dutch which have been studied by Kirsner (1976). While this study brings out much interesting material, a number of Kirsner's conclusions do not stand up under scrutiny. While Kirsner claims that Dutch passives involve "backgrounding of the agent," the examples in $\$ 7$ show that the Passive chomeur in many examples is not an Agent. The examples in (39) show the incorrectness of his conclusion that the Dutch impersonal passive "refers only to human activities." The present paper also provides evidence against Kirsner's conclusion that in Dutch impersonal passives "there is no grammatical subject." In so doing, it provides a means of achieving Kirsner's goal of accounting for the sameness of morphology in personal and impersonal passives. Kirsner's proposal that passive morphology appears when "the logical subject is not the grammatical subject" does not account for the lack of passive morphology in sentences such as

(ii) Er fluiten jongens.

'There whistle boys.'

since jongens can be shown not to be the final 1 in (ii). 10. The Active Dummy Law also plays another role in connection with impersonal passives - that of preventing networks such as (iii)

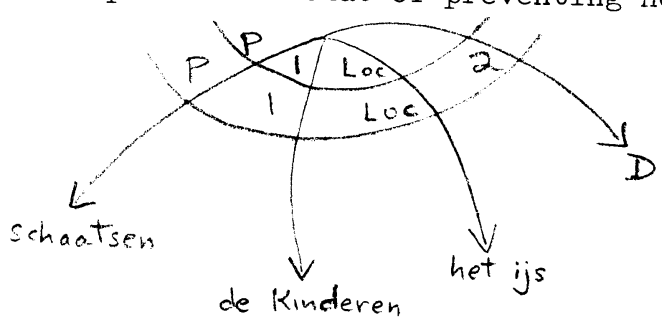

(iii) is like (7), the network associated with (1), except that in (iii) the dummy heads a 2 -arc in the second stratum without heading a l-arc in the third stratum. Such networks are ruled out by the Active Dummy Law. For discussion, see Perlmutter (in preparation a).

1l. See Harris (1976, to appear a, b) and Perlmutter (to appear a, b).

12. I will not attempt to justify the Inversion analysis here beyond pointing out how it automatically accounts for the impossibility of passives. However, semantic considerations of the type stressed in Perlmutter (to appear b) suggest such an analysis. Note that in the Dutch and English examples cited 
the Inversion nominal is semantically a Cognizer, while in the Turkish examples it is an Experiencer. Note further that in languages for which a number of syntactic tests of l-hood are available, such as Italian [Perlmutter (to appear a)], the corresponding nominals behave like ls with respect to those tests. 13. See Zaenen (1976).

14. (126) arbitrarily represents zor gelmek as a simple predicate, ignoring the question of whether it has internal structure, and if so, how it is to be represented.

\section{$\underline{\text { References }}$}

Boas, Franz and Ella Deloria (1939) Dakota Grammar (Memoirs of the National Academy of Sciences, Vol. 23).

Breckenridge, Janet (1975) Rules that Nothing Undergoes (Unpublished honors dissertation, Harvard University).

Comrie, Bernard (1977) "In Defense of Spontaneous Demotion: The Impersonal Passive," in Peter Cole and Jerrold Sadock (eds) Syntax and Semantics 8: Grammatical Relations, Academic Press, New York.

Harris, Alice C. (1976) Grammatical Relations in Modern Georgian (Unpublished doctoral dissertation, Harvard University).

Harris, Alice C. (to appear a) "Case Marking, Agreement, and Inversion in Udi," in Perlmutter (to appear c).

Harris, Alice C. (to appear b) "Inversion as a Rule of Universal Grammar: Georgian Evidence," in Perlmutter (to appear c).

Harris, Alice C. (to appear c) Georgian Syntax: A Study in Relational Grammar.

Jain, Jagdish (1977) "The Hindi Passive in Universal Grammar" (Unpublished paper, San Francisco State University).

Keenan, Edward L. (1975) "Some Universals of Passive in Relational Grammar," Papers from the Eleventh Regional Meeting of the Chicago Linguistic Society.

Kirsner, Robert S. (1976) "On the Subjectless 'PseudoPassive' in Standard Dutch," in Charles Li (ed.) Subject and Topic, Academic Press, New York.

Maling, Joan and Annie Zaenen (to appear) "The Nonuniversality of a Surface Filter," Linguistic Inquiry.

Perlmutter, David M. (to appear a) "Evidence for Inversion in Italian," in Perlmutter (to appear c).

Perlmutter, David M. (to appear b) "Evidence for Inversion in Russian, Japanese, and Kannada," in Perlmutter (to appear c).

Perlmutter, David M. (ed.) (to appear c) Studies in Relational Grammar 1.

Perlmutter, David M. (in preparation a) "The Active Dummy Law." 
Perlmutter, David M. (in preparation b) "Multiattachment and the Unaccusative Hypothesis: Auxiliary Selection in Italian."

Perlmutter, David M. (in preparation c) "The Unaccusative Hypothesis."

Perlmutter, David M. and Paul M. Postal (1974) Lectures on Relational Grammar, Summer Linguistic Institute of the LSA, University of Massachusetts at Amherst.

Perlmutter, David M. and Paul M. Postal (1977) "Toward a Universal Characterization of Passivization," Proceedings of the Third Annual Meeting of the Berkeley Linguistics Society.

Perlmutter, David M. and Paul M. Postal (to appear a)

"Some Proposed Laws of Basic Clause Structure," in Perlmutter

(to appear $\mathrm{c}$ ).

Perlmutter, David M. and Paul M. Postal (to appear b) "The 1-Aảvancement Exclusiveness Law," in Perlmutter (to appear c).

Perlmutter, David M. and Paul M. Postal (to appear c)

"The Relational Succession Law," in Perlmutter (to appear c).

Postal, Paul M. (in preparation) "The Unaccusative Hypothesis."

Sapir, Edward (1917) Review of Uhlenbeck (1916), International Journal of American Linguistics 1, 82-86.

Uhlenbeck, C.C. (1916) "Het Passieve Karakter van het Verbum

Transitivum of van het Verbum Actionis in Talen van

Noord-Amerika," Verslagen en Mededeelingen der Konink$\frac{\text { lijke Akademie van Wetenschappen, Afdeeling Letterkunde, }}{\text { Vijfde Reeks, Tweede Deel, 187-216. }}$

Zaenen, Annie (1976) "3-2 Advancement and Clause Union in Dutch" (Unpublished paper, Harvard/MIT). 